\title{
The Anterolateral Thigh Flap: Clinical Applications and Review of the Literature
}

\author{
Peter L Deptula, Travis J Miller, Lawrence Z Cai and Gordon K Lee* \\ Department of Plastic Surgery, Stanford University Medical Center, California

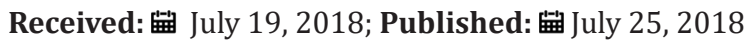

*Corresponding author: Gordon K Lee, Department of Plastic Surgery Residency Stanford Plastic \& Reconstructive Surgery, Director of Microsurgery \& Professor of Surgery Program Director, 770 Welch Road, Suite 400, MC: 5715 Palo Alto, CA 94304-5715, Italy,

\begin{abstract}
The anterolateral thigh (ALT) flap has gained popularity in reconstructive surgery in recent years as its advantages have come to be widely recognized. We report the senior author's experience over a five-year period with the use of the ALT flap. The ALT flap is a highly versatile flap that can be used to reconstruct a variety of defects. The flap's concealed donor site scar, decreased need for skin grafting, decreased donor site morbidity and great versatility make it a first-line option for many different types of defects.
\end{abstract}

Keywords: Anterolateral Thigh Flap; Soft Tissue Reconstruction; Outcomes; Free Tissue Transfer; Myocutaneous; Fasciocutaneous

Abbreviations: ALT: Anterolateral Thigh; LCFA: Lateral Circumflex Femoral Artery; ASIS: Anterior Superior Iliac Spine

\section{Introduction}

Free tissue transfer for the repair of complex defects is a mainstay of modern reconstructive surgery [1]. Reconstruction with the anterolateral thigh (ALT) flap was first described by Song and colleagues as a septocutaneous flap [2]. However, studies have shown that in the majority of cases, the vascular supply arises from musculocutaneous perforators through the vastus lateralis from the descending or transverse branches of the lateral circumflex femoral artery (LCFA) or the LCFA itself [3-9]. The ALT offers the advantages of a long and robust pedicle [5,6,10,11], a significant volume of soft tissue $[9,12,13]$, the option of a sensate flap $[14,15]$, a pedicled option for regional reconstruction [16-20], and the ability to operate using a two-team approach with no patient repositioning. In addition, the flap offers an excellent donor site aesthetic result when closed primarily. Due to these advantages, the ALT flap has become a workhorse for reconstruction of the head and neck [2123], extremity [24-26], trunk [27-29], and perineum [17,30-35]. Potential pitfalls of the ALT flap include an extended operating time due to delicate dissection of musculocutaneous perforators [10] and poor aesthetic outcome if the donor site requires a skin graft. We present a single surgeon clinical experience in the reconstruction of complex defects using the ALT flap and highlight the flap's extremely versatile features.

\section{Methods}

We prospectively collected data of all patients who underwent ALT flap reconstruction over a 5 year period for any reconstruction of any complex wound. We evaluated age, indications, composition, complications, and outcomes. Patients were evaluated post- operatively for complications, recovery of function, return to work, and resumption of sporting activities. For patients undergoing genitoperineal reconstruction, return to sexual activity and normal urination were also evaluated.

\section{Surgical Technique}

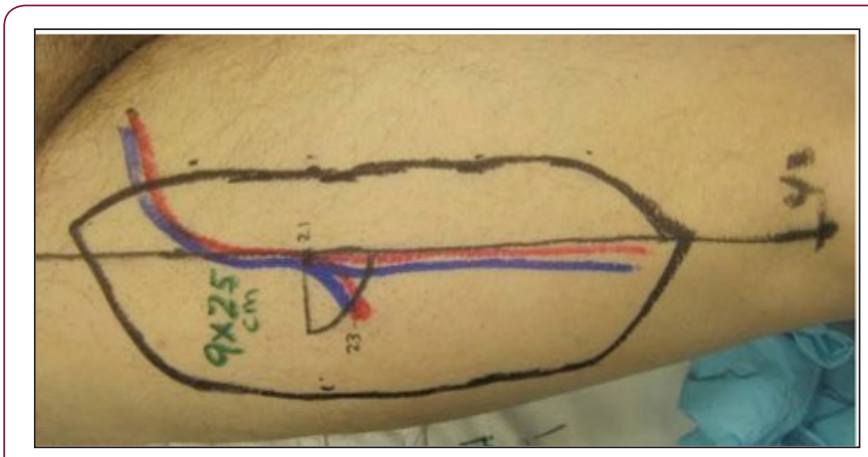

Figure 1: The anterolateral thigh is marked preoperatively. The vascular pedicle is mapped out with confirmation by Doppler ultrasound.

With the patient supine, a line is marked from the anterior superior iliac spine (ASIS) to the superior aspect of the lateral border of the patella $[9,13,36]$. Centered at the midpoint of this line, a medially-oriented semi-circle with a radius of $3 \mathrm{~cm}$ is marked, indicating the site at which the primary perforator will be found. Presumptive sites of additional perforators are marked at $5 \mathrm{~cm}$ both distal and proximal to the primary perforator along the ASISpatellar line $[3,4,6,10]$ (Figure 1). Perforators are then confirmed 
by Doppler ultrasound. At this point, a template of the defect is used to mark out the skin paddle. Intraoperatively, in the intermuscular septum between the rectus femoris and the vastus lateralis, the LCFA and its branches, and venae comitantes are identified. Perforators are identified and followed.

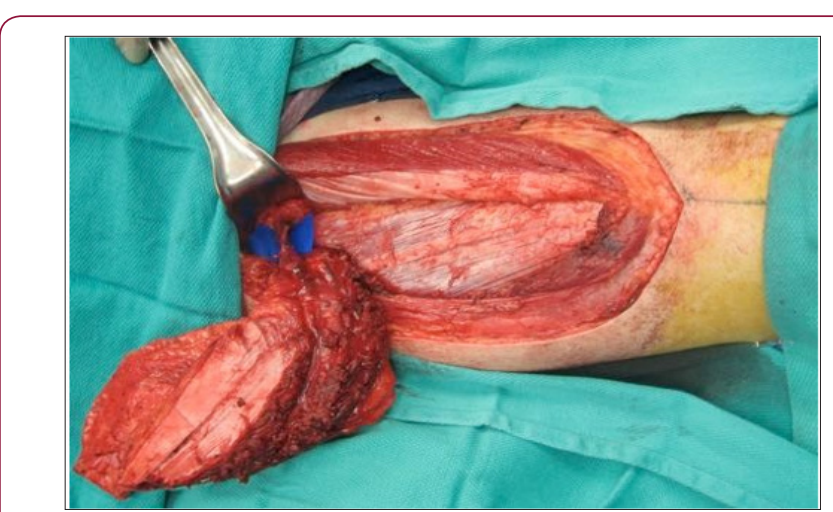

Figure 2: The ALT flap is elevated. The pedicle is seen within the intermuscular septum between the vastus lateralis and rectus femoris muscles.

If a perforator from either the transverse branch or descending branch of the LCFA or LCFA itself is identified, the flap can be raised as a septocutaneous flap. In the majority of cases, $[4,6]$ perforators are musculocutaneous, and the ALT must be elevated either as a perforator flap with careful intramuscular dissection, or with a variable amount of vastus lateralis muscle (Figure 2). To raise the ALT as a sensate flap, the lateral femoral cutaneous nerve must be included and may necessitate proximal and lateral extension of the incision. Once the flap is raised and the pedicle transected, the donor site can be closed primarily in defects up to $12 \mathrm{~cm}$ in width, depending upon the laxity of the skin. The fascia lata is not approximated and a closed suction drain is placed at the donor site.

\section{Results}

A total of 31 ALT flaps were included in this study. Twenty-five free ALT flaps were used to reconstruct defects of the head and neck (Figures 3 \& 4). Four flaps were used to reconstruct defects of the lower extremity (Figure 5). Two pedicled, sensate ALT flaps were used for total penile reconstruction with neourethra creation using tube-in-a-tube design and neurorraphy to the pudendal nerve. All cases and outcomes are summarized in the attached table (Table 1). In the two patients who underwent penile reconstruction, return to normal urination and sexual activity was reported, and both patients reported satisfaction with full sensation of the flaps.

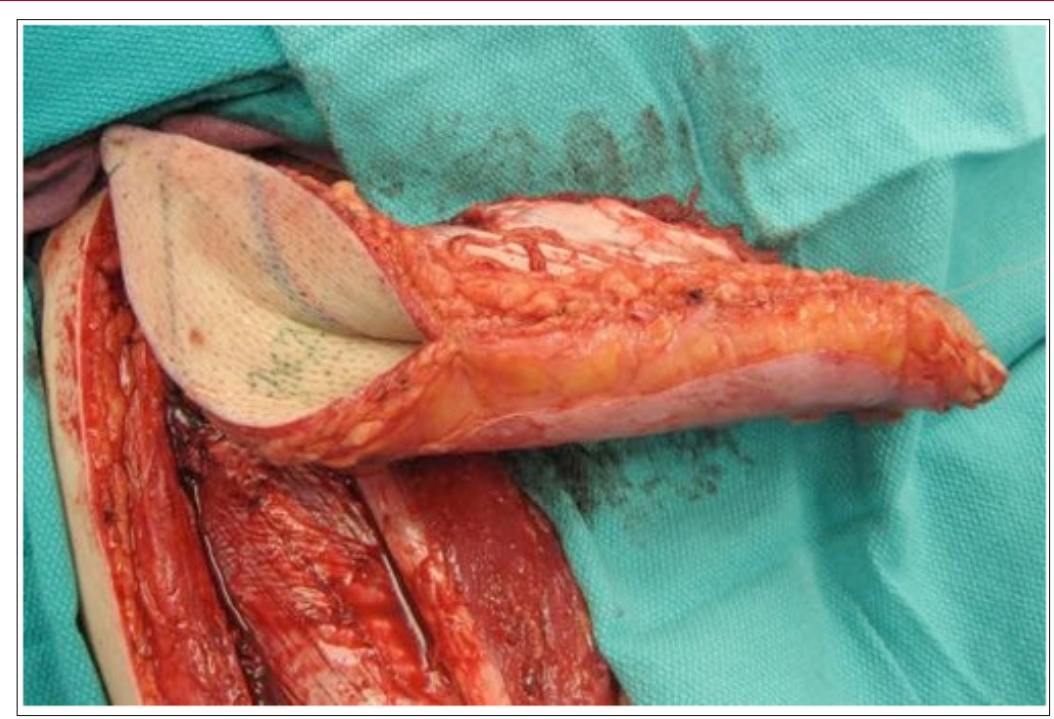

Figure 3: An ALT flap is tubularized for esophageal reconstruction.

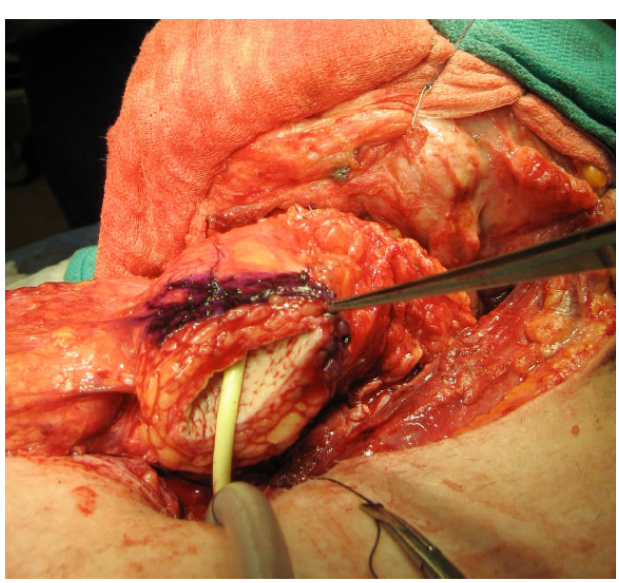

Figure 4: A tubularized ALT flap is inset for esophageal reconstruction. 
Table 1: Overview of 31 patients with complex defects treated with anterolateral thigh flap reconstruction.

\begin{tabular}{|c|c|c|c|c|c|}
\hline No & Age (Y) & Defect & Flap Characteristics & Complications & Outcome \\
\hline 1. & 69 & Orbit, skull base & Musculocutaneous & None & Healed flap \\
\hline 2. & 56 & FOM & Fasciocutaneous & None & Healed flap \\
\hline 3. & 55 & FOM & Fasciocutaneous Tubularized & None & healed flap \\
\hline 4. & 70 & Cervical esophagus & fasciocutaneous & None & return to normal diet \\
\hline 5. & 36 & Orbit, maxilla & Musculocutaneous & None & healed flap \\
\hline 6. & 40 & Total tongue & Musculocutaneous & None & healed flap \\
\hline 7. & 54 & Total tongue & neurotized to hypoglossal & None & fxn \\
\hline 8. & 43 & Total tongue & Musculocutaneous & None & healed flap \\
\hline 9. & 73 & Orbit & Fasciocutaneous & None & healed flap \\
\hline 10. & 48 & Oropharynx & Fasciocutaneous & None & healed flap \\
\hline 11. & 22 & Dorsal foot & $\begin{array}{l}\text { Neurotized to superficial peroneal } \\
\text { nerve }\end{array}$ & None & $\begin{array}{l}\text { ambulates independently, } \\
\text { retains sensation }\end{array}$ \\
\hline 12. & 63 & Total penectomy & $\begin{array}{c}\text { Pedicled, neurotized to pudendal } \\
\text { nerve }\end{array}$ & $\begin{array}{l}\text { Urethrocutaneous fistula, } \\
\text { required secondary surgery } \\
\text { to revise }\end{array}$ & $\begin{array}{l}\text { return to sexual function, } \\
\text { normal urination }\end{array}$ \\
\hline 13. & 43 & Orbit Upper lip and cheek & Fasciocutaneous & $\begin{array}{c}\text { Partial flap necrosis } \\
\text { managed with debridement } \\
\text { and STSG }\end{array}$ & healed flap \\
\hline 14. & 57 & recurrence & Fasciocutaneous & None & healed flap \\
\hline 15. & 55 & $\begin{array}{l}\text { Type IIIB Tibia-Fibula } \\
\text { fracture }\end{array}$ & Musculocutaneous & None & ambulates independently \\
\hline 16. & 58 & Anterior and lateral neck & Fasciocutaneous & None & healed flap \\
\hline 17. & 63 & Cervical esophagus & Tubularized & None & healed flap \\
\hline 18. & 23 & $\begin{array}{c}\text { Total penectomy } \\
\text { Orbit, dural involvement } \\
\text { with CSF }\end{array}$ & $\begin{array}{c}\text { Pedicled, neurotized to pudendal } \\
\text { nerve }\end{array}$ & $\begin{array}{l}\text { Urethrocutaneous fistula, } \\
\text { required secondary surgery } \\
\text { to revise }\end{array}$ & $\begin{array}{c}\text { return to sexual fxn, normal } \\
\text { urination }\end{array}$ \\
\hline 19. & 35 & rhinorrhea & Musculocutaneous & None & $\begin{array}{l}\text { healed flap, resolution of } \\
\text { rhinorrhea }\end{array}$ \\
\hline 20. & 58 & Maxilla and skull base & Musculocutaneous & $\begin{array}{c}\text { Venous congestion, } \\
\text { managed with revision of } \\
\text { venous anastamosis }\end{array}$ & healed flap \\
\hline 21. & 41 & $\begin{array}{l}\text { Type IIIB Tibia-Fibula } \\
\text { Fracture }\end{array}$ & Musculocutaneous & None & $\begin{array}{l}\text { ambulates independently, } \\
\text { return to work }\end{array}$ \\
\hline 22. & 61 & $\begin{array}{l}\text { Recurrence after prior FFF } \\
\text { reconstruction }\end{array}$ & $\begin{array}{l}\text { Bone resection, recon plate, } \\
\text { fasciocutaneous ALT }\end{array}$ & None & healed flap \\
\hline 23. & 62 & Total tongue & Musculocutaneous & $\begin{array}{l}\text { Flap failure salvaged with } \\
\text { pectoral }\end{array}$ & healed flap \\
\hline 24. & 70 & Total tongue & Musculocutaneous & None & healed flap \\
\hline 25. & 53 & $\begin{array}{c}\text { Cervical esophagus } \\
\text { Mandible, FOM, chin, neck }\end{array}$ & Tubularized fasciocutaneous & None & healed flap \\
\hline 26. & 56 & lips & FFF, Fasciocutaneous ALT & $\begin{array}{l}\text { Partial flap necrosis } \\
\text { managed with debridement } \\
\text { and primary closure }\end{array}$ & healed flap \\
\hline 27. & 55 & $\begin{array}{l}\text { Mandible, chin, cheek, FOM, } \\
\text { and neck }\end{array}$ & $\begin{array}{l}\text { FFF, Fasciocutaneous ALT, TFL as } \\
\text { sling for lower lip }\end{array}$ & $\begin{array}{l}\text { Arterial thrombosis, flap } \\
\text { failure, contralateral ALT } \\
\text { salvage (case \#31) }\end{array}$ & healed flap \\
\hline 28. & 65 & Esophagus & Tube-in-tube fasciocutaneous & $\begin{array}{l}\text { Abscess, delayed healing, } \\
\text { reoperation, re-closure }\end{array}$ & $\begin{array}{l}\text { healed flap healed flap, } \\
\text { return to normal diet }\end{array}$ \\
\hline 29. & 50 & Cervical esophagus & Tubularized fasciocutaneous & $\begin{array}{l}\text { Flap dehiscence and partial } \\
\text { necrosis managed with } \\
\text { debridement and closure }\end{array}$ & $\begin{array}{l}\text { healed flap, return to } \\
\text { normal diet }\end{array}$ \\
\hline 30. & 81 & Proximal lower extremity & Supercharged reverse ALT & None & ambulates independently \\
\hline 31. & 55 & $\begin{array}{c}\text { Mandible, chin, cheek, FOM, } \\
\text { neck }\end{array}$ & Fasciocutaneous & None & healed flap \\
\hline
\end{tabular}




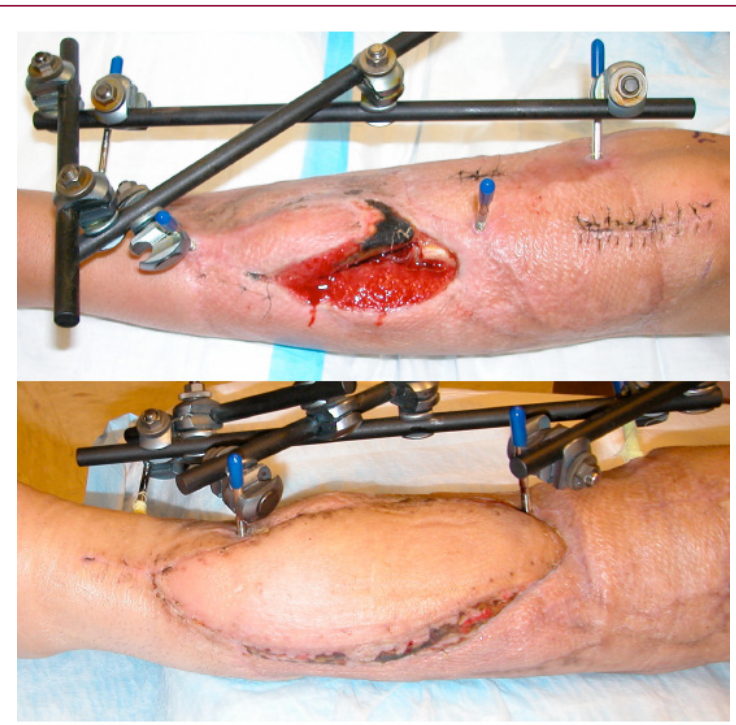

Figure 5: ALT flap for lower extremity reconstruction. Preoperative defect (above). Postoperative result after coverage with free ALT flap (below).

The patient receiving a sensate flap for lower extremity reconstruction reported adequate protective sensation. The patient who received a musculocutaneous flap neurotized to the hypoglossal nerve was able to maintain adequate oral intake. As expected, anesthesia of the flap and progressive atrophy of denervated muscle was noted in all other cases. Five donor sites required skin grafting; all others were closed primarily. Follow-up ranged from two months to four years, with an average follow-up of 12.4 months. Return to activities including participation in athletics was noted, except where limited by extensive lower extremity injury. There were two instances of total flap loss (6\%). Partial flap loss occurred in three patients. No donor site complications were noted.

\section{Discussion}

One of the major advantages of the ALT is the variety of available tissue that can be elevated, thereby permitting adipofascial, fasciocutaneous, and myocutanous flaps [9,12,13,37,38]. In cases where patients' body mass index is high, extensive subcutaneous tissue can be a potential pitfall when a thin, pliable flap is needed. In this case, thinning of the ALT either primarily or as a secondary procedure allows for further customization of this versatile flap to the defect [39]. While some cadaver studies suggest a degree of vascular compromise in thinned flaps [40], other authors have found that this practice can be performed safely [41]. The ALT as a flap of choice over other workhorse flaps is in part due to the lack of functional morbidity [42] and excellent donor site aesthetic outcome [41]. Donor sites as large as $12 \mathrm{~cm}$ in our study were closed primarily, without complication. It has been suggested that even larger defects can be closed if fascial closure is also performed [43]. However, this technique increases the risk of elevated compartmental pressures and remains a concern in light of recent reports of ALT donor site compartment syndrome [44].

Pre-operative assessment of patients undergoing reconstruction with an ALT flap remains an evolving area. Some authors advocate for preoperative angiography in patients in whom popliteal pulsations are lacking, and lower thresholds for immediate arterial reconstruction using a venous graft [45]. For routine preoperative evaluation, color Doppler flowmetry [46], CT angiography, and CT-guided stereotaxy [47] have all been established as effective. However, these techniques have not been shown to be superior to traditional pencil Doppler evaluation along with clinical exam. Tedious intramuscular dissection of perforating vessels can prolong operative time significantly $[5,10,48,49]$. Dissection is eased by taking a small cuff of surrounding vastus lateralis muscle, which also reduces the risk of vascular injury [49]. This technique can even be used in cases where a thin, pliable flap is desired, as the denervated muscle cuff will atrophy over time.

\section{Conclusion}

The advantages of the ALT flap are numerous: a long and robust pedicle, the option of a sensate flap pedicled flap for regional reconstruction, flexibility in volume and tissue types with or without thinning, shortened operating time of a two team approach without repositioning, and superior donor site outcome. In our experience, these benefits outweigh the potential pitfalls of extended operating time and unsatisfactory aesthetic outcome if the donor site requires a skin graft. In the former case, a small muscle cuff can greatly ease the flap harvest. In the latter, the ALT donor site is less exposed than other flaps that provide equally large volumes of tissue, and produces no functional morbidity at the donor site. For these reasons, the highly customizable ALT has become a versatile and reliable workhorse flap for a variety of complex soft tissue defects at our center.

\section{References}

1. Antia NH and Buch VI. (1971) Transfer of an abdominal dermo-fat graft by direct anastomosis of blood vessels. Br J Plast Surg 24(1): 15-19.

2. Song YG, Chen GZ, and Song YL (1984) The free thigh flap: a new free flap concept based on the septocutaneous artery. Br J Plast Surg 37(2): 149-159.

3. Choi SW, Park JY, Hur MS, Park HD, Kang HJ, et al. (2007) An anatomic assessment on perforators of the lateral circumflex femoral artery for anterolateral thigh flap. J Craniofac Surg 18(4): 866-871. 
4. Kawai K, Imanishi N, Nakajima H, Aiso S, Kakibuchi M, et al. (2004) Vascular anatomy of the anterolateral thigh flap. Plast Reconstr Surg 114(5): 1108-1117.

5. Koshima I, Fukuda H, Utunomiya R, Soeda S (1989) The anterolateral thigh flap; variations in its vascular pedicle. Br J Plast Surg 42(3): 260262.

6. Malhotra K, Lian TS, Chakradeo V (2008) Vascular anatomy of anterolateral thigh flap. Laryngoscope. 118(4): 589-592.

7. Nojima K, Brown SA, Acikel C, Arbique G, Ozturk S, et al. (2005) Defining vascular supply and territory of thinned perforator flaps: part I. Anterolateral thigh perforator flap. Plast Reconstr Surg 116(1): 182-193.

8. Uysal AC, Lu F, Mizuno H, Ogawa R, Vinh VQ et al. (2006) Defining vascular supply and territory of thinned perforator flaps: part I. Anterolateral thigh perforator flap. Plast Reconstr Surg 118(1): 288-289.

9. Zhou G, Qiao Q Chen GY, Ling YC, Swift R (1991) Clinical experience and surgical anatomy of 32 free anterolateral thigh flap transplantations. $\mathrm{Br}$ J Plast Surg 44(2): 91-96.

10. Kimata Y, Uchiyama K, Ebihara S, Nakatsuka T, Harii K (1998) Anatomic variations and technical problems of the anterolateral thigh flap: a report of 74 cases. Plast Reconstr Surg 102(5): 1517-1523.

11. Shimizu T, Fisher DR, Charmichael SW, Bite U (1997) An anatomic comparison of septocutaneous free flaps from the thigh region. Ann Plast Surg 38(6): 604-610.

12. Wolff, KD and Grundmann A (1992) The free vastus lateralis flap: an anatomic study with case reports. Plast Reconstr Surg 89(3): 469-75; discussion 476-477.

13. Xu DC, Zhong SZ, Kong JM, Wang GY, Liu MZ, et al. (1988) Applied anatomy of the anterolateral femoral flap. Plast Reconstr Surg 82(2): 305-310.

14. Felici N, Felici A (2006) A new phalloplasty technique: the free anterolateral thigh flap phalloplasty. J Plast Reconstr Aesthet Surg 59(2): 153-157.

15. Ribuffo D, Cigna E, Gargano F, Spalvieri C, Scuderi N (2005) The innervated anterolateral thigh flap: anatomical study and clinical implications. Plast Reconstr Surg 115(2): 464-470.

16. Ozkan O, Ozkan $O$ (2009) The prefabricated pedicled anterolateral thigh flap for reconstruction of a full-thickness defect of the urethra. J Plast Reconstr Aesthet Surg 62(3): 380-384.

17. Rubino C, Figus A, Dessy LA, Alei G, Mazzocchi M, et al. (2009) Innervated

\section{ISSN: 2574-1241}

DOI: 10.26717/BJSTR.2018.07.001473

Gordon K Lee. Biomed J Sci \& Tech Res

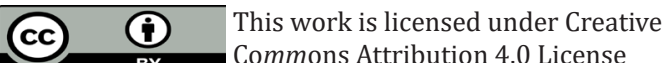

Submission Link: https://biomedres.us/submit-manuscript.php island pedicled anterolateral thigh flap for neo-phallic reconstruction in female-to-male transsexuals. J Plast Reconstr Aesthet Surg 62(3): e4549.

18. Tzeng YS, Yu CC, Chou TD, Chen TM, Chen SG (2008) Proximal pedicled anterolateral thigh flap for reconstruction of trochanteric defect. Ann Plast Surg 61(1): 79-82

19. Hunter CL, Skinner EC, Lee GK (2015) Reconstruction with Pedicled Anterolateral Thigh Flap After Wide Local Excision of Penoscrotal Extramammary Paget's Disease: A Case Report and Comprehensive Literature Review. Eplasty 15: e26.

20. Komorowska Timek E, Gurtner G, Lee GK (2010) Supercharged reverse pedicle anterolateral thigh flap in reconstruction of a massive defect: A case report. Microsurgery 30(5): 397-400.

21. Wolff KD, Kesting M, Thurmuller P, Bockmann R, Holzle F (2006) The anterolateral thigh as a universal donor site for soft tissue reconstruction in maxillofacial surgery. J Craniomaxillofac Surg 34(6): 323-331.

22. Yu P (2004) Characteristics of the anterolateral thigh flap in a Western population and its application in head and neck reconstruction. Head Neck 26(9): 759-769.

23. Komorowska-Timek E, Lee GK (2014) Tube-in-a-tube anterolateral thigh flap for reconstruction of a complex esophageal and anterior neck defect. Ann Plast Surg 72(1): 64-66.

24. Koshima I, Fujutsu M, Ushio S, Sugiyama N, Yamshita S (2005) Flowthrough anterior thigh flaps with a short pedicle for reconstruction of lower leg and foot defects. Plast Reconstr Surg 115(1): 155-162.

25. Lin $\mathrm{CH}$, Wei FC, Lin YT, Yeh JT, Rodriguez Ede J, et al. (2006) Lateral circumflex femoral artery system: warehouse for functional composite free-tissue reconstruction of the lower leg. J Trauma 60(5): 1032-1036.

26. Wang HT, Fletcher JW, Erdmann D, Levin LS (2005) Use of the anterolateral thigh free flap for upper- extremity reconstruction. J Hand Surg Am 30(4): 859-864.

27. Kaplan JL, Allen RJ, Guerra A, Sullivan SK (2003) Anterolateral thigh flap for breast reconstruction: review of the literature and case reports. J Reconstr Microsurg 19(2): 63-68.

28. Wei FC, Suominen S, Cheng MH, Celik N, Lai YL (2002) Anterolateral thigh flap for postmastectomy breast reconstruction. Plast Reconstr Surg 110(1): 82-88.

29. Luan A, Galvez MG, Lee GK (2016) Flow-through omental flap to free anterolateral thigh flap for complex chest wall reconstruction: Case report and review of the literature. Microsurgery 36(1): 70-76.

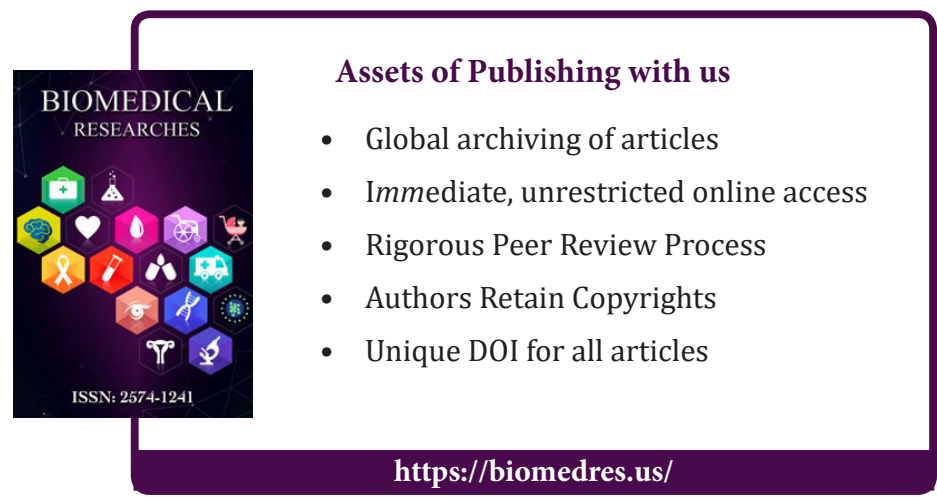

Cite this article: Gordon K L, Peter L D, Travis J M, Lawrence Z C. The Anterolateral Thigh Flap: Clinical Applications and Review of the 